\title{
A uniform analysis for concessive at least and optative at least*
}

\author{
Patrick Georg Grosz \\ University of Tübingen
}

\begin{abstract}
This paper discusses a particular type of optative constructions (which are constructions that express a wish without containing an overt lexical item that means wish): If-clauses in which optativity is apparently licensed by at least. I propose that the connection between at least and optativity is indirect and can be explained as follows. On the one hand, if-clauses generally have an optative reading; on the other hand, optative at least is an instance of concessive at least, which conveys desirability and thus supports ('cues') an optative reading. I propose that, as a consequence, the licensing of optativity by at least is a semantic conspiracy: I argue that there is a pragmatic preference for using optativity cues, which blocks optative readings in cue-less utterances.
\end{abstract}

Keywords: optative, concessive, at least

\section{The core questions}

Optatives are constructions that express a wish, regret, hope or desire without containing an overt lexical item that means wish, regret, hope or desire (e.g. Quirk et al. 1985, Scholz 1991, Rosengren 1993, Rifkin 2000, Kyriakaki 2007, 2008, 2009, Asarina \& Shklovsky 2008, Biezma 2011ab, Grosz 2011ab). An example is given in (1a), which conveys the wish paraphrased in (1b). It is crucial that native speakers judge (1a) to be a complete utterance, as opposed to an incomplete conditional clause, cf. Rifkin 2000. In other words, we cannot classify

\footnotetext{
${ }^{*}$ The content of this paper is based on my PhD dissertation, Grosz 2011b. All of the research for this paper was carried out in affiliation with the Massachusetts Institute of Technology. I am especially grateful to my co-advisors Kai von Fintel and Sabine Iatridou, and to my committee members Irene Heim and David Pesetsky. I also wish to thank Danny Fox, Martin Hackl and Norvin Richards for discussions and extensive comments that have contributed to this dissertation project; this project has also benefited from exchanges with Adam Albright, Josef Bayer, Sigrid Beck, Bronwyn Bjorkman, Gennaro Chierchia, Cleo Condoravdi, Norbert Corver, Ev Fedorenko, Hans-Martin Gärtner, Ted Gibson, Caroline Heycock, Gerhard Jaeger, Angelika Kratzer, Manuel Križ, Sven Lauer, Victor Manfredi, Diane Massam, Lisa Matthewson, Jason Merchant, Rick Nouwen, Pritty Patel-Grosz, Masha Polinsky, Paul Portner, Donca Steriade, David Stifter, Josh Tenenbaum, Hubert Truckenbrodt, Rob Truswell, Igor Yanovich and Ede Zimmermann.
} 
an utterance as an optative if native speakers judge it as an incomplete, fragmentary utterance that cannot stand on its own.
(1) a. If only the sandwiches had been edible!
b. I wish the sandwiches had been edible.

Optatives typically contain particles that appear to be obligatory and thus may be classified pre-theoretically as licensors of optativity. In English, only, just and but occur in optatives, as shown in (2). Their apparent obligatoriness is shown in (3). None of the utterances in (3) can be used to express a wish, and they appear to be incomplete conditionals in a sense in which the optatives in (2) are not.

(2) a. If I'd only listened to my parents!

b. If I could just make them understand my point of view!

c. If I could but explain!

(Quirk et al. 1985: 842)

(3) a. \# If I'd listened to my parents!

b. \# If I could make them understand my point of view!

c. \# If I could explain!

The larger research question that this paper addresses can be stated as follows: How do we account for this apparent obligatoriness of particles in optatives? In addressing this question, we face an apparent compositionality problem. Can we derive the core meaning of an optative like (1a) compositionally from the standard meaning of an if-clause and the standard meaning of the particle only?

The answer that I propose radically differs from previous approaches to optativity. ${ }^{1}$ I reject the idea that optativity arises compositionally from the standard meaning of if-clauses and the standard meaning of particles. In contrast, I argue that optativity is inherently independent from the presence of such particles. To account for the quasi-obligatoriness of such particles, I argue that the semantics of the particles conspires with the semantics of an optative utterance, giving rise to the connection that we observe.

In this paper, I focus on a sub-question of the above, and discuss a variant of optatives that is cross-linguistically well-represented (cf. Scholz 1991 for German, Biezma 2011b for Spanish), but does not seem to exist in English: optatives that are apparently licensed by at least. The relevant construction is schematically illustrated in (4), where the superscripted hash marks in parentheses

\footnotetext{
${ }^{1}$ For English if only optatives, previous approaches include Rifkin (2000), Asarina \& Shklovsky (2008), and Biezma (2011ab).
} 
mark the fact that (4a-b) are typically not accepted as complete utterances by native speakers of English. ${ }^{2}$ A well-formed German example is given in (5).

(4) a. ${ }^{(\#)}$ If at least the sandwiches had been edible!

b. ${ }^{\#)}$ If I could at least make them understand my point of view!

(5) Wenn ich mich wenigstens hinsetzen könnt'!

if I me at.least sit.down could

'If I could at least sit down!'

(adapted and shortened from Scholz 1991: 102)

Within the larger research question introduced above, this paper analyzes the role of at least in such optatives: What does it contribute to such constructions and how does it function as a licensor?

\section{The proposal}

On a general note, I argue that particles in optatives involve weaker readings than their standard counterparts, specifically they only convey meaning at the level of non-truth-conditional meaning. As shown in Grosz 2011b, this can be argued for only-type particles, at least-type particles and the particle doch/toch that we find in German and Dutch. In the present paper, I focus on AT LEAST ${ }^{3}$ in optatives, the truth-conditional vacuity of which can be schematized as in (6). (I model its nontruth-conditional component as a definedness condition. It is beyond the scope of this paper to address whether it is most appropriately analyzed as presuppositional meaning or in terms of conventional implicature.)

\section{(6) If defined, $\|\operatorname{AT} \operatorname{LEAST}(\phi)\|=\|\phi\|$.}

I argue that optative AT LEAST (i.e. the AT LEAST that licenses optatives) is a variant of Nakanishi \& Rullmann's (2009) concessive AT LEAST, a natural example of which is given in (7).

\footnotetext{
${ }^{2}$ Biezma (2011b) argues that such at least optatives do exist in English, corroborated by some naturally occurring examples in her footnote 22 . Correspondingly, Biezma leads us to expect that (4a-b) are well-formed, something that is also consistent with my proposal. However, native speakers of English that I consulted reject Biezma's examples and my (4a-b). It is beyond the scope of this paper to determine why English should differ from other languages in this regard.

${ }^{3}$ I use small caps to mark an element in the object-language, or a specific reading of such an element, that has counterparts in various languages. In this sense, "(concessive) AT LEAST" is an abbreviation for "(concessive) at least in English and its equivalents in other languages (such as German wenigstens)". Correspondingly, italicized at least always means "AT LEAST in English".
} 
A Uniform Analysis for Concessive 'At Least' and Optative 'At Least'

\section{(7) Well, at least you won something!}

My own rendering of Nakanishi \& Rullmann's analysis is given in (8), with the auxiliary definitions in (9). ${ }^{4}$
a. $\quad \|$ AT LEAST (concessive) $^{\mathrm{g}, \mathrm{c}}=\lambda \mathrm{S} . \lambda \mathrm{C} . \lambda \mathrm{p}$ :
b. $\quad \mathrm{S}$ is a bouletic ordering $\wedge$
BOULETIC
c. $\quad \exists r \in g(C)\left[r>_{s} p\right] \wedge$
NOT THE BEST
d. $\quad \exists q \in g(C)\left[p>_{S} q\right]$.
NOT THE WORST
e.
$\mathrm{p}$
IDENTITY

(9) a. A scale $S$ is defined as a set of ordered pairs of propositions $(\mathrm{S} \subseteq \wp(\mathrm{W}) \times \wp(\mathrm{W}))$

b. For any $S$, I use $\mathrm{p}_{1}>_{\mathrm{S}} \mathrm{p}_{2}$ to mean ' $\mathrm{p}_{1}$ is strictly higher than $\mathrm{p}_{2}$ on $\mathrm{S}$ '.

c. For any $S$, I use $\mathrm{p}_{1} \geq_{\mathrm{S}} \mathrm{p}_{2}$ to mean ' $\mathrm{p}_{1}$ is equivalent to $\mathrm{p}_{2}$ or higher than $\mathrm{p}_{2}$ on $\mathrm{S}$ '

Stating (8) in words, concessive AT LEAST has the following properties: It is a truth-conditionally vacuous element, (8e), and combines with a scale $S$ and a proposition $p$, as well as a contextually salient set of propositions $C$. At the level of non-truth-conditional meaning it restricts the scale $S$ to a bouletic scale, (8b), and presupposes that there is a contextually salient proposition that is more preferable than the modified proposition $p,(8 \mathrm{c})$, as well as a contextually salient proposition that is less preferable, (8d). This gives rise to the 'settling for less' effect that Nakanishi \& Rullmann (2009) document: concessive AT LEAST conveys that the modified proposition does not describe the optimal, most desirable situation, but that it does not describe the worst, least desirable situation either. For the example in (7), the above analysis can be illustrated as in (10). As shown in (10a-b), the proposition you (i.e. the hearer) won something is contained in a set of salient alternatives $\mathrm{C}$, with respect to which it is ranked on a salient scale S. If defined, the particle at least is truth-conditionally vacuous in (7), shown in (10c). Finally, at least is defined iff all of the following three conditions are met. First, (10d-i), the salient scale $\mathrm{S}$ is a bouletic scale (i.e. propositions that are higher on $\mathrm{S}$ are more preferable than propositions that are lower). Second, (10d-ii), there is a higher (i.e. more preferable) contextual alternative $r$. Third, (10d-iii), there is a lower (i.e. less preferable) contextual alternative $q$. In the typical context in which (7) can be uttered, both is the case. The hearer could have won exactly the prize that she desired most, satisfying (10d-ii), but she could have also won nothing, satisfying (10d-iii).

\footnotetext{
${ }^{4}$ These auxiliary definitions are loosely based on work in Klinedinst 2005, Villalta 2007.
} 
(10) a. $\quad \mathrm{C}=\{$ you won nothing, you won something (but not the prize that you wanted to win), you won the prize that you wanted to win, ...

b. $\quad S=$ you won the prize that you wanted to win $>_{S}$ you won something (but not the prize that you wanted to win) $>_{\mathrm{S}}$ you won nothing

c. If defined, $\|$ at least $\mathbf{s , \mathbf { C }}$ you won something $\|=\|$ you won something $\|$.

d. $\quad$ at least $t_{\mathbf{s}, \mathbf{C}}$ you won something $\|$ is defined iff

i. $\quad \mathrm{S}$ is a bouletic ordering,

ii. $\quad \exists r \in g(C)\left[r>_{S}\right.$ you-won-something]

iii. $\exists \mathrm{q} \in \mathrm{g}(\mathrm{C})$ [you-won-something $>_{\mathrm{S}} \mathrm{q}$ ]

One of the core contributions of the present paper is the proposal that crosslinguistically, if AT LEAST serves to license optativity, we are always dealing with the truth-conditionally vacuous concessive AT LEAST, and never with the more canonical AT LEAST, which conveys that the modified proposition and possibly more is the case (Nakanishi \& Rullmann's epistemic AT LEAST). I present arguments for this proposal in section 3 .

\section{Cross-linguistic evidence}

So far, I have presented my proposal that AT LEAST in optatives should be analyzed as Nakanishi \& Rullmann's (2009) concessive AT LEAST, as rendered in (8) above. This sets it apart from the more canonical reading of AT LEAST, rendered in (11), ${ }^{5}$ which Nakanishi \& Rullmann (2009) call epistemic AT LEAST. ${ }^{6}$
a. $\quad \|$ AT LEAST (epistemic) $\|^{\mathrm{g}, \mathrm{c}}=\lambda \mathrm{S} . \lambda \mathrm{C} \cdot \lambda \mathrm{p} . \lambda \mathrm{w}$ :
b. $\quad \exists \mathrm{w}^{\prime}\left[\operatorname{Epist}(\mathrm{w})\left(\mathrm{w}^{\prime}\right) \wedge \exists \mathrm{q} \in \mathrm{C}\left[\mathrm{q}>_{\mathrm{s}} \mathrm{p} \wedge \mathrm{q}\left(\mathrm{w}^{\prime}\right)=1\right]\right]$.
c. $\quad \exists \mathrm{q} \in \mathrm{C}[\mathrm{q} \geq \mathrm{s} p \wedge \mathrm{q}(\mathrm{w})=1]$
UNCERTAINTY
MINIMUM

Epistemic AT LEAST, illustrated in (12), asserts that the modified proposition or some higher scalar alternative is true, and conveys at a non-truth-conditional level that it is possible (though not certain) that some higher scalar alternative is true.

(12) In the accident, there were at least 5 casualties.

\footnotetext{
${ }^{5}$ Example (11) is my adaptation of Nakanishi \& Rullmann's entry, who, in turn, acknowledge Krifka 1999, Geurts \& Nouwen 2007 and Büring 2008 as the basis of their analysis. I differ by treating the uncertainty contribution as a definedness condition, while they treat it as a conventional implicature. This is a distinction that I will not be concerned with in this paper.

${ }^{6}$ Note that epistemic AT LEAST also has an impact at the truth-conditional at issue level, cf. (11c), whereas concessive AT LEAST does not contribute anything on the truth-conditional level, cf. (8e).
} 
I will now provide evidence that optative AT LEAST is concessive AT LEAST and not epistemic AT LEAST. To do so I start by reviewing a relevant diagnostic.

In English, Nakanishi \& Rullmann (2009) observe that concessive readings are preferred for sentence-initial at least, (13b), and excluded if at least is located between the verb and the direct object, (13a).

(13) a. Mary won at least a silver medal. (only epistemic reading)

b. At least Mary won a silver medal. (concessive reading preferred)

(Nakanishi \& Rullmann 2009: slide 6)

The distinction between concessive AT LEAST and epistemic AT LEAST entails various differences between the two types of AT LEAST (see Nakanishi \& Rullmann 2009). The difference that is most crucial for my project can be stated as follows. In the case of epistemic AT LEAST, it is odd to negate all higher alternatives, as illustrated in (14) and (15). Due to the position of at least, (14a) and $(15 \mathrm{a})$ do not have a concessive AT LEAST reading, making them semantically ill-formed, as opposed to (14b) and (15b).

(14) a. \# Mary didn't win a gold medal, but she won at least a silver medal.

b. Mary didn't win a gold medal, but at least she won a silver medal.

(Nakanishi \& Rullmann 2009: slide 7)

(15) a. \# Mary doesn't have three children, but she has at least two.

b. Mary doesn't have three children, but at least she has two.

(Nakanishi \& Rullmann 2009: slide 7)

The ability of AT LEAST to occur in clauses such as (14) and (15) can thus be taken to be a diagnostic for a concessive reading. I now provide three arguments that optative AT LEAST is concessive AT LEAST.

The first argument is based on German. Let me first show that German has both a designated concessive AT LEAST, wenigstens, and a designated epistemic AT LEAST, mindestens. Example (16) shows that wenigstens 'at least', but not mindestens 'at least', has a concessive reading. Only the former passes the diagnostic that we introduced above.

(16) Maria hat kein Gold gewonnen, aber wenigstens /\#mindestens Silber. Maria has no gold won but at.least at.least silver 'Maria didn't win gold, but at least she won silver.'

In turn, example (17) shows that wenigstens 'at least' does not have an epistemic reading, while mindestens 'at least' does (cf. Gast (2011), who also observes that 
wenigstens is ill-formed in a statement like (17)). As Nakanishi \& Rullmann (2009) observe, the use of concessive AT LEAST (but not epistemic AT LEAST) conveys that there is a salient more preferable alternative as well as a less preferable alternative. The intuition in (17) is that wenigstens 'at least' conveys that more casualties (six, seven, eight, ...) would have been better than five, but five casualties is better than less casualties (four, three, two, ...); this renders the utterance pragmatically odd. ${ }^{7}$

$$
\begin{aligned}
& \text { Bei dem Unfall gab es mindestens / \#wenigstens fünf Tote. } \\
& \text { at the accident gave it at.least at.least five casualties } \\
& \text { 'There were at least five casualties in the accident.' }
\end{aligned}
$$

In short, we have established that mindestens only has an epistemic AT LEAST reading and wenigstens only has a concessive AT LEAST reading. It is easy to show that optatives require the latter. As shown in (18), only wenigstens 'at least' can be used to license an optative.

(18) Wenn Hans wenigstens / \#mindestens auf Maria gehört hätte!
if Hans at.least at.least to Maria listened had
'If only Hans had at least listened to Maria!'

Example (18) is thus a first argument that optative AT LEAST is concessive AT LEAST. The second argument consists of the observation that, as expected if optative AT LEAST is concessive AT LEAST, we find the following. In many languages that can use an at least-type item in optatives, the same item also has a concessive AT LEAST reading while lacking an epistemic AT LEAST reading. This includes Romanian măcar, Polish chociaż, Russian xotja and Finnish edes, the first two of which are illustrated in (19) and (20). ${ }^{8}$

Example (19a) is an at-least optative in Romanian, licensed by the item măcar 'at least'; (19b) shows that măcar 'at least' cannot occur in prototypical contexts

\footnotetext{
${ }^{7}$ A question that arises is naturally why (17) automatically generates the preference scale in (i) and not the inverted preference scale in (ii). If the preference scale in (ii) could be selected, (17) should be perfectly well-formed. It is beyond the scope of this paper to account for this observation. It is also worth pointing out that this observation holds for all instances of concessive AT LEAST, both in optative and non-optative constructions.

i. $\quad \ldots>$ six casualties $>_{\text {preferable }}$ five casualties $>>_{\text {preferable }}$ four casualties $>\ldots$

ii. $\quad \ldots>$ four casualties $>$ preferable five casualties $>_{\text {preferable }}$ six casualties $>\ldots$

${ }^{8}$ For translations and consultation, I thank: Mikko Kupula (Finnish); Grzegorz Michalski, Bożena Rozwadowska, Bartosz Wiland (Polish); Gianina Iordachioaia, Andreea Nicolae (Romanian); Aysa Arylova, Natasha Ivlieva, Alexander Podobryaev, Igor Yanovich (Russian).
} 
in which epistemic AT LEAST is found, and (19c-d) show that măcar 'at least' passes our diagnostic for concessive AT LEAST. ${ }^{9}$

\section{(19) Romanian}

a. Dacă Jon măcar ar fi ascultat de Mary! if Jon at.least had listened of Mary

'If only John had at least listened to Mary!'

b. Sunt cel puţin/*măcar patru mere în punga asta.

are at least at.least four apples in bag this

'There are at least four apples in this bag.'

c. Maria nu a câştigat medalia de aur, dar măcar a câştigat medalia Maria notwon medal of gold but at.leastwon medal de argint.

of silver

'Mary didn't win a gold medal, but at least she won a silver medal.'

d. Maria nu are trei copii, dar măcar are doi.

Maria not has three children but at.least has two

'Mary doesn't have three children, but at least she has two.'

Polish is parallel to Romanian. We find at-least optatives that employ chociaz 'at least', (20a), but again chociaz 'at least' cannot occur in epistemic AT LEAST contexts, (20b). As shown in (20c-d), chociaz 'at least' passes our diagnostic for concessive AT LEAST, mirroring the facts from Romanian.

(20) Polish

a. Gdyby/Żeby Jan chociaż (po)słuchał Marii!

if if John at.least listen.(perf.)pret.3sg.m Mary.gen.nom.f 'If at least Jan had listened to Mary!'

b. W torbie są co najmniej/ \# chociaż cztery jabłka. in bag are at least at.least four apples

'In this bag, there are at least four apples.'

c. Marie nie zdobyła złotego medalu, ale chociaż zdobyła srebrny. Mary not receive gold medal but at.least receive silver 'Mary didn't win a gold medal, but at least she won a silver medal.'

d. Marie nie ma trojga dzieci, ale ma chociaż dwoje. Mary not has three children but has at.least two 'Mary doesn't have three children, but at least she has two.'

\footnotetext{
${ }^{9}$ Romanian măcar 'at least' and Finnish edes 'at least' also have another reading as NPI EVEN. See Grosz (2011b) for discussion, Rullmann \& Nakanishi (2009) for the even-at least connection.
} 
The third argument for an analysis of optative AT LEAST as concessive AT LEAST stems from the following prediction. Some languages employ a variant of AT LEAST in optatives that can have an epistemic AT LEAST reading; my proposal predicts that any such variant of AT LEAST is ambiguous between a concessive AT LEAST reading and an epistemic AT LEAST reading (the former of which is what occurs in optatives). This prediction can be confirmed for all such elements that I have looked at, including Greek tulachiston, Hebrew le-faxot, Czech aspon̆ and Spanish al menos. The Greek and Hebrew cases are illustrated in (21) and (22). ${ }^{10}$

Example (21a) shows that Greek tulachiston 'at least' can license an optative utterance. As shown in (21b), tulachiston has an epistemic AT LEAST reading, i.e. it is completely natural in a clause that states something undesirable such as there being five casualties. Nevertheless, (21c-d) show that tulachiston also has a concessive AT LEAST reading; it passes the test from Nakanishi \& Rullmann 2009 that I have introduced and applied above.

(21) Greek

a. An tulachiston o Yannis iche akusi tin Maria!

if at.least the Yannis had.3sg listened the Maria.acc

lit. 'If Yannis had at least listened to Maria!'

b. Sto aftokinitistiko atixima, skotothikan tulachiston pende anthropi. in-the car accident were.killed at.least five people

'There were at least 5 casualties in the traffic accident.'

c. I Maria dhen kerdhise chriso metalio, ala tulachiston kerdhise the Maria not won gold medal but at.least won arjiro/asimenjo (metalio) silver medal 'Mary didn't win a gold medal, but at least she won a silver medal.'

d. I Maria dhen echi tria pedhja, ala tulachiston echi dhio. the Maria not has three children but at.least has two 'Mary doesn't have three children, but at least she has two.'

Hebrew mirrors the Greek facts. As shown in (21a), le-faxot 'at least' can be used to license an optative utterance. This particle also has an epistemic AT LEAST reading, shown in (21b). Once again, it also passes the test for a concessive AT LEAST reading, as shown in $(21 \mathrm{c}-\mathrm{d})$.

\footnotetext{
${ }_{10}$ For translations and consultation, I thank: Ivona Kučerová, Radek Šimík (Czech); Lila Daskalaki, Marios Mavrogiorgos, Dimitris Michelioudakis (Greek); Micha Breakstone, Hadas Kotek (Hebrew); Luis Alonso-Ovalle, Paula Menendez-Benito (Spanish).
} 
A Uniform Analysis for Concessive 'At Least' and Optative 'At Least'

(22) Hebrew

a. lu John haya le-faxot makSiv le-Mary!

if.cf John be.past.3sg to-less listen.pres.3sg to-Mary

lit. 'If John/he had at least listened to Mary!'

b. be-te'unat ha-drax-im hayu le-faxot xamiSa harug-im in-accident the-way-pl exist.masc-pl at-least five casualties

'There were at least 5 casualties in the traffic accident.'

c. Mary lo zaxta be-medalyat zahav, aval le-faxot hi zaxta

Mary not won in-medal gold but at-least she won be-medalyat kesef.

in-medal silver

'Mary didn't win a gold medal, but at least she won a silver medal.'

d. le-Mary eyn SloSa yeladim, aval le-faxot yes 1-a Snayim.

to-Mary not.exist three children but at-least exist to-her two

'Mary doesn't have three children, but at least she has two.'

Such languages thus verify the following prediction, as stated above. If we find an apparently canonical (i.e. epistemic) variant of AT LEAST in an optative, this lexical item must be ambiguous between an epistemic reading and a concessive reading. This follows if optative AT LEAST is always concessive AT LEAST.

\section{The effect of placing concessive at least into an optative}

In the preceding sections, I have argued that optative AT LEAST is an occurrence of concessive AT LEAST. I would now like to briefly illustrate the main effect of placing concessive AT LEAST into an optative. Let us look at a sample optative, where we can see that wenigstens 'at least' has the semantics of concessive AT LEAST, as introduced in (8). Consider the scenario in (23a), which gives rise to the preference scale in (23b) (loosely adapted from Villalta 2007).

(23) a. Context: Sofia promised to bring dessert to my picnic, but I forgot to tell her my preferences. My favorite dessert is chocolate cake; apple pie is acceptable but less preferable; I hate vanilla ice cream. As a matter of fact, Sofia ended up bringing vanilla ice cream.

b. most preferable chocolate cake $>$ apple pie $>$ vanilla ice cream least preferable 
In such a scenario, the following judgments hold. I can utter an optative to express a wish for a chocolate cake (the best possible scenario), as in (24b), as well as to express a wish for an apple pie (the 'settling for less' scenario), as in (25b). ${ }^{11}$

$\begin{array}{lllllll}\text { a. Jetzt } & \text { kommt die } & \text { mit Vanilleeis } & \text { daher! } & \ldots \\ \text { now } & \text { comes } & \text { she } & \text { with vanilla.ice.cream } & \text { here } & \end{array}$

'Now she arrives with vanilla ice cream!'

b. Wenn sie doch/\#wenigstens einen Schokokuchen gebracht hätte! if she doch \#at.least a chocolate.cake brought had 'If [doch/\#at least] she had brought a chocolate cake!'
a. Jetzt kommt die mit Vanilleeis daher! ... now comes she with vanilla.ice.cream here 'Now she arrives with vanilla ice cream!'

b. Wenn sie wenigstens $/^{\text {? }}$ doch einen Apfelkuchen gebracht hätte! if she at.least ${ }^{\text {? }}$ doch a apple.cake brought had 'If [at least $/$ ?' doch] she had brought an apple pie!'

Crucially, wenigstens 'at least' is only possible in (25b), where the modified proposition (she brought an apple pie) is not the best possible case, i.e. where there is a better alternative (namely: she brought a chocolate cake). In contrast, wenigstens 'at least' is impossible in (24b), where the modified proposition (she brought a chocolate cake) is the best possible case. As illustrated in (27), this follows directly from the semantics in (8), repeated in (26), due to the meaning component in (26c): ${ }^{12}$ There must be a better alternative in order for wenigstens 'at least' to be licensed, cf. (27d-ii); this is satisfied in (25b), but not in (24b).

$$
\begin{array}{ll}
\text { a. } & \| \text { AT LEAST } \\
\text { b. } & \mathrm{S} \text { is a bouletic ordering } \|^{\mathrm{g}, \mathrm{c}}=\lambda \mathrm{S} . \lambda \mathrm{C} . \lambda \mathrm{p}: \\
\text { c. } & \exists \mathrm{r} \in \mathrm{g}(\mathrm{C})\left[\mathrm{r}>_{\mathrm{S}} \mathrm{p}\right] \wedge \\
\text { d. } & \exists \mathrm{q} \in \mathrm{g}(\mathrm{C})\left[\mathrm{p}>_{\mathrm{S}} \mathrm{q}\right] . \\
\text { e. } & \mathrm{p}
\end{array}
$$

\section{BOULETIC NOT THE BEST NOT THE WORST IDENTITY}

\footnotetext{
${ }^{11}$ To construct a minimal pair, I contrast wenigstens 'at least' with doch; doch on its own seems to imply optimality, making it marked in a wish for the non-optimal apple pie, (25b). This is however not a strong constraint on doch and I will not be discussing this further (cf. Grosz 2011b).

12 The meaning components in $(8 b) /(26 b)$ (the modified proposition is ordered with respect to alternative propositions in terms of their desirability) and (8d)/(26d) (there is a contextually salient alternative that is less preferable than the modified proposition) are trivially present in any optative, even in the absence of AT LEAST, so we cannot learn anything from looking at them.
} 

a. $\quad \mathrm{C}=\{$ Sofia brought apple pie, Sofia brought chocolate cake, Sofia brought vanilla ice cream $\}$

b. $\quad S=$ Sofia brought chocolate cake $>_{S}$ Sofia brought apple pie $>_{S}$ Sofia brought vanilla ice cream

c. If defined, $\|$ at least s, $_{\text {C }}$ she brought an apple pie $\|=\|$ she brought an apple pie $\|$.

d. $\quad \mid$ at least $\mathbf{s}_{\mathbf{S}, \mathrm{C}}$ she brought an apple pie\| is defined iff

i. $\mathrm{S}$ is a bouletic ordering,

ii. $\exists \mathrm{r} \in \mathrm{g}(\mathrm{C})\left[\mathrm{r}>_{\mathrm{S}}\right.$ apple-pie $]$

iii. $\exists \mathrm{q} \in \mathrm{g}(\mathrm{C})$ [apple-pie $>_{\mathrm{S}} \mathrm{q}$ ]

The requirement for a salient alternative that is more preferable than the modified proposition accounts for one intuition that native speakers share: if-at-least optatives are often less natural than corresponding if-only-optatives and cannot occur in an out-of-the-blue context, as illustrated in (28). This follows directly from the requirement in (26c) that there be a salient, more preferable alternative.

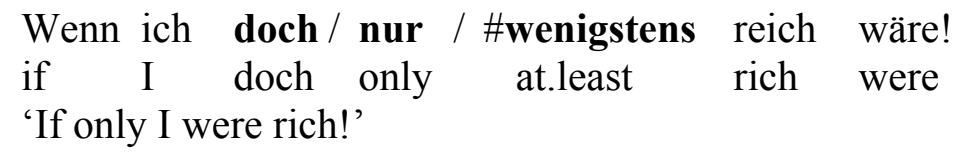

If we introduce such a salient, more preferable alternative overtly, as shown in (29), wenigstens 'at least' becomes natural in an utterance identical to (28).
a. Ach, wenn ich doch nur allmächtig und berühmt wäre! oh if I doch only omnipotent and famous were 'If only I were omnipotent and famous!'
b. Oder wenn ich wenigstens reich wäre! or if I at.least rich were 'Or at least if only I were rich!'

A more natural example is given in (30).

(30) a. Ach, wenn sie doch einen Schokokuchen gebracht hätte! oh if she doch an chocolate.cake brought had 'If only she had brought an chocolate cake!'

b. Oder wenn sie wenigstens einen Apfelkuchen gebracht hätte! or if she at.least an apple.cake brought had 'Or if at least she had brought an apple cake!' 
Notably, the more preferable alternative need not be overtly introduced; it can simply be implied, as in (31). Here, various more preferable alternatives can be construed, such as I never came to this concert, or the concert is already over, or the concert is taking place in a church. No matter how the reader/hearer resolves the search for a relevant alternative, wenigstens 'at least' will be licensed, due to the availability of a salient, more preferable alternative.

(31) Erst viertel auf zehn? ... Mir kommt vor, ich sitz' schon drei Stunden in dem Konzert. Ich bin's halt nicht gewohnt ... Was ist es denn eigentlich? Ich muß das Programm anschauen ... Ja, richtig: Oratorium! Ich hab' gemeint: Messe. Solche Sachen gehören doch nur in die Kirche! Die Kirche hat auch das Gute, daß man jeden Augenblick fortgehen kann. - Wenn ich wenigstens einen Ecksitz hätt'!

'Only quarter past nine? ... I feel like I've been sitting in this concert for three hours. Well, I'm not used to it ... What is it anyway? I'll have to look at the program ... Yes, of course: An oratorio! I meant: A mass. Such things belong into a church! A church also has the advantage that one can leave at any time. - If at least I had a corner seat!'

(A. Schnitzler. 1900. Leutnant Gustl.) ${ }^{13}$

At this point we have not yet said anything about how to derive optativity as such. The next section is dedicated to this question.

\section{The Meaning of Optatives and the Generalized $E X$ Operator}

To derive the wish that optatives convey, I propose that optative utterances are a variant of exclamative utterances, the meaning of which is due to a null operator $E X$ (see Grosz 2011 b for argumentation in favor of $E X$ ). EX selects a contextually salient scale and conveys that the modified proposition exceeds a salient threshold $\xi$ on that scale. In optatives, the relevant scale reflects the speaker's preferences, cf. (32); typically the threshold $\xi$ marks the boundary between tolerable circumstances (including, in (32), circumstances in which Sofia brought apple pie) and intolerable circumstances (circumstances that in the utterance context of (32) are less preferable than ones in which Sofia brought apple pie).

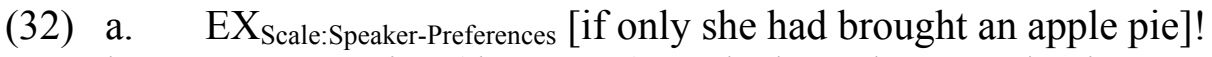

b. Core meaning (due to EX): [p she brought an apple pie] exceeds the threshold $\xi$ on a scale that reflects the speaker's preferences in the utterance context.

\footnotetext{
${ }_{13}$ Available online at: http://www.zeno.org/nid/20005630711 (Zenodot Verlagsgesellschaft mbH)
} 
I assume that both if- and that-clauses can be complements to $E X$. As argued in Grosz 2011b, this allows us to uniformly account for optatives with the form of ifclauses, such as the above, and optatives with the form of that-clauses, (33a), as well as polar exclamatives (utterances that express surprise at a fact), (33b). All of these exclamative utterances contain the operator $E X$. Polar exclamatives differ from optatives in that they combine not with a preference scale, but with a scale that models surprisingness or shockingness (possibly a speaker-oriented subjective unlikelihood scale).

(33) a. Oh, that I had told them both a year ago! (Martin F. Tupper. 1851. The Twins; A Domestic Novel.) ${ }^{14}$

b. That you could ever want to marry such a man! (Quirk et al. 1985: 841)

It follows that optativity does not compositionally arise from the presence of the particles that we find in optatives. My approach sides with scholars such as Rosengren (1993), who assume that particles are prototypical rather than obligatory for optatives (i.e. optatives do not require particles, but they are most natural if they do contain particles), against scholars who argue that particles are obligatory in optatives (e.g. Pittner 2007).

How does the quasi-obligatoriness of particles in optatives arise? I argue that it is due to a semantic conspiracy. As discussed above, $E X$ contributes generalized exclamativity, one shade of which is optativity, while particles (such as AT LEAST) contribute non-truth-conditional meaning (such as a settling-for-less attitude in the case of AT LEAST). I now explore their interaction. First of all, utterances with the shape of an optative typically have various readings, some of which are more marked than others. If we assume that $E X$ can freely combine with if-clauses, then (34a) has an optative reading, given in (34c). However, according to native speakers' intuitions, (34a) can only be understood as an incomplete, fragmentary conditional, and not as an optative; so (34c) must be somehow blocked. As Scholz (1991) observes, based on extensive corpus research, optatives are relatively rare, from which we may infer that the non-optative reading in (34b) is more readily accessible. This alone will, however, not suffice to block the optative reading in (34c). In fact, based on what we know about ambiguity resolution, one may expect the fragmentary nature (and thus ill-formedness) of (34b) to be sufficient to make the well-formed reading in (34c) accessible. So why would native speakers nevertheless judge (34a) to be ill-formed, and the (34c) reading to be unavailable? In what follows, I argue that the blocking of the reading in (34c) is due to extra-grammatical principles that govern successful communication.

${ }^{14}$ Available online at: http://www.gutenberg.org/files/16574/16574-h/16574-h.htm 

a. \# Wenn sie einen Apfelkuchen gebracht hätte! if she a apple.cake brought had 'If she had brought an apple pie!'
b. unmarked reading: \# conditional antecedent (fragmentary)
c. $\quad$ marked reading: $\quad \checkmark$ optative utterance (complete, but blocked)

First, I propose that particles bias marked readings, due to implicatures that they trigger or due to incompatibility with unmarked readings. In the case of wenigstens 'at least', this is plausibly due to the fact that the particle conveys the desirability of the modified proposition (cf. (17) and the discussion thereof).

The core idea is that an element like wenigstens 'at least' can reverse interpretive preferences, as in (35), which contrasts with (34). In this sense, wenigstens 'at least' serves as a cue (or bias) for an optative reading; for now, I define (semantic) cue as an element that makes a less salient reading more salient.
a. Wenn sie wenigstens einen Apfelkuchen gebracht hätte! if she at.least a apple.cake brought had 'If she had brought an apple pie!'
b. dispreferred unmarked reading: \# conditional antecedent
c. $\quad$ preferred marked reading: $\quad \checkmark$ optative utterance

We now need to address the two following questions: First, why does concessive AT LEAST act as a cue for optativity? Second, why are optative readings like (34c) (provided they exist, which is what I argue for) unavailable in absence of a cue, even if the only competing reading (in (34b)) is independently ruled out?

I propose that AT LEAST cues optativity due to its semantic contribution. Consider first the complete conditional in (36a) and the elliptical conditional in (36b) (a continuation rise on hätte 'had' marks (36b) as an incomplete utterance). In contexts in which the intended consequent can be inferred, (36b) may be licensed; what we observe, similar to what we saw in (17), is that (36a-b) cannot be uttered without the speaker conveying a positive evaluation of it rained, due to the semantics of wenigstens 'at least'. In this sense, (36a-b) end up conveying desirability very much like the desirability conveyed by the optative in (36c) (which differs from (36b) in its intonation pattern: Optatives typically have a falling intonation). The core contribution of an optative is to convey desirability of the modified proposition; as discussed, concessive AT LEAST does so, too, thus smoothing out the categorical difference in meaning between a non-optative utterance such as (36a-b) and an optative utterance such as (36c). I propose that this is sufficient to make an optative reading of an if-clause more salient: while it may initially be marked to utter an if-clause with an optative reading, the independent marking of desirability can make such an intention evident. 
A Uniform Analysis for Concessive 'At Least' and Optative 'At Least'

(36) a. Wenn es wenigstens geregnet hätte, wäre ich zuhause geblieben. if it at.least rained had were I at.home stayed

'If at least it had rained, I would have stayed at home.'

b. Ja, wenn es wenigstens geregnet hätte ... (elliptical conditional)

c. Wenn es wenigstens geregnet hätte! (optative)

We have thus seen how concessive AT LEAST can act as a cue for optativity; it simply conveys desirability, thus making an expression of desirability (which is what optativity is all about) more salient.

We can now proceed to account for the obligatoriness of cues, i.e. the deviant status of (34a) with the intended reading in (34c). If (34c) is technically an available reading for (34a), and (34b) is ill-formed anyway, why does (34c) not become available? (Or: why is (34c) so hard, if not impossible, to access?) I propose to account for this by making standard assumptions on rational discourse participants, using Lewis's (1969) signaling games. I have argued that particles like wenigstens 'at least' act as cues for an independently available optative reading. In terms of Lewis's (1969: 130-133) signaling games, speakers and hearers have to commit to certain communicative strategies in order to allow for successful communication. In our examples, this entails that a speaker has to decide whether to use an optativity cue (such as AT LEAST), as in (35), or not, as in (34); correspondingly, a hearer has to decide how to disambiguate a cue-less, ambiguous utterance like (34a) (assuming, for simplicity, that (35a) is unambiguously optative). Let us further assume (for simplicity) that there are cues for optative readings, but no cues for the more canonical non-optative readings. If we now assume that cues are minimally costly (i.e. the utility of successful communication with a cue is slightly lower than the utility of successful communication without a cue), we can derive that cues will always be used when the context does not independently provide a strong bias for an optative interpretation. This can be illustrated as in (37) below. Assume that the speaker $(s)$ has to decide whether to utter an optative with a cue (CUE), e.g. (35a) to mean (35c), or without a cue $(\neg$ CUE), e.g. (34a) to mean (34c). Assume further that the hearer $(h)$ has to decide whether to interpret a cue-less, ambiguous utterance as an optative (OPT), as in (34c), or as a non-optative conditional fragment $(\neg \mathrm{OPT})$, as in (34b). Finally, assume that misunderstanding has a utility of 0 for both discourse participants, understanding without effort (i.e. without cues) has a utility of 2 and understanding with effort (i.e. with cues) has a utility of 1 . (These numbers are arbitrary and merely reflect a preference order between the three scenarios. ${ }^{15}$ ) We

\footnotetext{
${ }^{15}$ In fact, the penalty for using cues is probably much lower, so it may be more realistic to assume a utility of 1.9 for understanding with effort (i.e. with cues). Determining the exact utilities would require experimental evidence, which is beyond the scope of this paper.
} 
then calculate the expected utilities ( $E U$ ) of a set of strategies (such as (37a)) as the sum of the respective probability that a speaker intends to utter an optative (abbreviated as $\rho$ ) and a non-optative conditional fragment $(1-\rho)$, multiplied by the corresponding payoffs. For instance, if the speaker commits to the strategy of not using cues for optativity ( $s \rightarrow \neg$ CUE) and the hearer commits to the strategy of disambiguating a cue-less if-clause towards a non-optative conditional antecedent $(h \rightarrow \neg \mathrm{OPT})$, the expected utility of this set of strategies would be as in $(37 \mathrm{a}){ }^{16}$ calculated as follows: in a situation, in which the speaker intends to utter an optative ( $s_{\text {opt }}$ with prior probability $\rho$ ), misunderstanding will arise, as the hearer will interpret the cue-less optative as non-optative (i.e. the first summand in calculating the expected utility in $(37 \mathrm{a})$ will be $0 \rho)$. In a situation in which the speaker intends to utter a non-optative conditional antecedent $\left(s_{\neg \text { opt }}\right.$ with prior probability $1-\rho$ ), effortless (i.e. cue-less) understanding will arise (i.e. the second summand in calculating the expected utility in (37a) will be $2(1-\rho))$. Adding the two values yields the expected utility of $2-2 \rho$, as given. The reader may now wish to verify the other expected utilities in $(37 b-d)$, which are calculated accordingly.

\begin{tabular}{|l|c|c|c|c|}
\hline & \multicolumn{2}{|c|}{$h \rightarrow \neg$ OPT } & \multicolumn{2}{c|}{$h \rightarrow$ OPT } \\
\hline$s \rightarrow \neg$ CUE & a. & $E U=2-2 \rho$ & c. & $E U=2 \rho$ \\
\hline$s \rightarrow$ CUE & b. & $E U=2-\rho$ & d. & $E U=\rho$ \\
\hline
\end{tabular}

Let us now assume, with Lewis (1969), that the most successful set of strategies is the one with the highest expected utilities. What becomes obvious is that the most successful set of strategies will always be (37b) if the context does not independently bias an optative reading (e.g. if $\rho=0.5$ ). Only if the prior probability of an optative reading is sufficiently high (in our illustration with the simplistic utilities 1,2 and 3 , this is the case if $\rho>0.66$ ), the strategies change and (37c) becomes the most efficient set of strategies. This derives the quasiobligatoriness of particles in optatives. It also predicts that we should find particle-free optatives in contexts that strongly bias an optative reading over alternative readings (in which case, the preferred strategies should be (37c)). (38) presents examples from German that are consistent with such a prediction.

$$
\begin{aligned}
& \text { a. Wenn ich deine Statur hätte! } \\
& \text { if I your build had } \\
& \text { 'If [only] I had your build!' }
\end{aligned}
$$$$
\text { (adapted from Evans 2007) }
$$

\footnotetext{
${ }^{16}$ I assume that the expected utilities of the speaker are identical to those of the hearer; correspondingly, I only write each expected utility once; $2-2 \rho$ can be seen as an abbreviation for $(2-2 \rho, 2-2 \rho)$, where the left term represents the speaker's EU and the right term the hearer's EU.
} 
b. Rico looked at the flowers and thought:

Wenn Stineli diese sehen könnte!

if Stineli these see could

'If [only] Stineli could see these!'

and stood at the fence for a long time without moving.

(Johanna Spyri. 1878. Heimatlos. First discussed in Grosz 2011a)

c. WÄRE ich zuhause geblieben!

WERE I at.home stayed

'HAD I [only] stayed home!' $\quad$ (Rosengren 1993:36)

d. Dass ich noch einmal Venedig sehen könnte!

that I still once Venice see could

'Oh that I could see Venice once more!' (Truckenbrodt 2006)

Further evidence for the independence of optativity from the semantics of prototypical particles stems from the paradigm in (39). As indicated, there is no single particle that is obligatory in an optative, i.e. either of them can license it, (39b-d); moreover, particles can combine quite freely, (39e-h). Another relevant observation (due to Scholz 1991) is that interjections, such as ach 'oh' can also license optatives, (39i). Only the construction without any such elements is illformed, (39j), corroborating the cue-like (non-obligatory) nature of such elements. This is reflected by the choice in (37) of referring to a generalized CUE element (which can be any of these particles) rather than a specific particle.

(39) a. Ach, wenn er doch nur wenigstens rechtzeitig gekommen wäre! oh if he doch only at.least in.time come were 'Oh, if only he had at least come in time!'

$\begin{array}{llrl}\text { b. } & \text { Wenn er doch } & \text { rechtzeitig gekommen } & \text { wäre! } \\ \text { c. } & \text { Wenn er nur } & \text { rechtzeitig gekommen } & \text { wäre! } \\ \text { d. } & \text { Wenn er } & \text { wenigstens rechtzeitig gekommen } & \text { wäre! } \\ \text { e. } & \text { Wenn er doch nur } & \text { rechtzeitig gekommen } & \text { wäre! } \\ \text { f. } & \text { Wenn er doch } & \text { wenigstens rechtzeitig gekommen } & \text { wäre! } \\ \text { g. } & \text { Wenn er nur wenigstens rechtzeitig gekommen } & \text { wäre! } \\ \text { h. } & \text { Wenn er doch nur } & \text { wenigstens rechtzeitig gekommen } & \text { wäre! } \\ \text { i. } & \text { Ach, wenn er } & \text { rechtzeitig gekommen } & \text { wäre! } \\ \text { j. \# } & \text { Wenn er } & \text { rechtzeitig gekommen } & \text { wäre! }\end{array}$

\section{Summary and Conclusion}

To summarize, I have argued that the prototypical particles that we find in optatives have a semantic contribution independent from optativity. Specifically, I have argued, based on cross-linguistic observations, that AT LEAST corresponds to 
what Nakanishi \& Rullmann (2009) call concessive AT LEAST whenever it serves to 'license' optativity. To account for the quasi-obligatoriness of particles, I have argued that their licensing function arises from independent communicative principles in the spirit of Lewis 1969: they make an optative reading of an ambiguous utterance salient in a context in which it is not independently biased, and as a consequence, speakers will always use them in such contexts.

\section{References}

Asarina, Alya, and Kirill Shklovsky. 2008. Optativity in English and Other Languages. Paper presented at MIT Ling-Lunch.

Biezma, Maria. 2011a. Optatives: Deriving Desirability from Scalar Alternatives. In Sinn und Bedeutung (SuB) 15, 117-132. Universaar - Saarland University Press, Saarbrücken.

Biezma, Maria. 2011b. Anchoring Pragmatics in Syntax and Semantics. Doctoral dissertation, University of Massachusetts at Amherst.

Büring, Daniel. 2008. The least 'at least' can do. In West Coast Conference on Formal Linguistics (WCCFL) 26, 114-120. Cascadilla Proceedings Project, Somerville, MA.

Evans, Nicholas. 2007. Insubordination and its uses. In Irina Nikolaeva (ed.), Finiteness. Theoretical and Empirical Foundations, 366-431. Oxford: Oxford University Press.

Gast, Volker. 2011. 'At least', 'wenigstens' and company: Negated universal quantification and the typology of focus quantifiers. Unpublished manuscript, Friedrich-Schiller-University of Jena.

Geurts, Bart, and Rick Nouwen. 2007. 'At least' et al.: The semantics of scalar modifiers. Language 83(3), 533-559. doi:10.1353/lan.2007.0115

Grosz, Patrick. 2011a. Facts and Ideals: On the Relationship Between Conditionals and Optatives. Sinn und Bedeutung (SuB) 15, 275-289. Universaar - Saarland University Press, Saarbrücken.

Grosz, Patrick. 2011b. On the Grammar of Optative Constructions. Doctoral dissertation, Massachusetts Institute of Technology.

Klinedinst, Nathan. 2005. Scales and 'Only'. Unpublished generals paper, UCLA.

Krifka, Manfred. 1999. At least some determiners aren't determiners. In Ken Turner (ed.), The Semantics/Pragmatics Interface from Different Points of View, 257-291. Oxford: Elsevier.

Kyriakaki, Maria. 2007. The meaning of $\mathrm{Na}$ and Conditional Wishes. Unpublished generals paper, University of Toronto.

Kyriakaki, Maria. 2008. The meaning of NA and Conditional Wishes. Paper presented at the Canadian Linguistic Association. University of Vancouver, Vancouver. May 31 - June 2, 2008. 
A Uniform Analysis for Concessive 'At Least' and Optative 'At Least'

Kyriakaki, Maria. 2009. When desiderative exclamations meet the conditionals: The case of Greek. Paper presented at Chronos 9th, International Conference on Tense, Aspect and Modality, Paris Diderot University, Paris, France. September 2 - 4, 2009.

Lewis, David. 1969. Convention. Cambridge, MA: Harvard University Press.

Nakanishi, Kimiko, and Hotze Rullmann. 2009. Epistemic and Concessive Interpretations of 'At Least'. Paper presented at CLA, Carleton University, May 24, 2009.

Pittner, Karin. 2007. Dialog in der Grammatik: Doch in Kausalsätzen mit Verberststellung. In Sandra Döring \& Jochen Geilfuß-Wolfgang (eds.), Von der Pragmatik zur Grammatik, 39-56. Leipzig: Universitätsverlag.

Quirk, Randolph, Sidney Greenbaum, Geoffrey Leech, and Jan Svartvik. 1985. A Comprehensive Grammar of the English Language. London: Longman.

Rifkin, Jay. 2000. If only if only were if plus only. In Chicago Linguistic Society (CLS) 36-1, 369-384. Chicago Linguistic Society, Chicago.

Rosengren, Inger. 1993. Imperativsatz und 'Wunschsatz' - zu ihrer Grammatik und Pragmatik. In Inger Rosengren (ed.), Satz und Illokution Band 2, 1-48. Tübingen: Niemeyer.

Rullmann, Hotze, and Kimiko Nakanishi. 2009. More About 'At Least'. Talk presented at the MOSAIC Workshop, Ottawa.

Scholz, Ulrike. 1991. Wunschsätze im Deutschen - Formale und funktionale Beschreibung. Satztypen mit Verberst- und Verbletztstellung. Tübingen: Niemeyer.

Truckenbrodt, Hubert. 2006. On the semantic motivation of syntactic verb movement to $\mathrm{C}$ in German. Theoretical Linguistics 32(3), 257-306. doi: 10.1515/TL.2006.018

Villalta, Elisabeth. 2007. Context Dependence in the Interpretation of Questions and Subjunctives. Doctoral dissertation, Universität Tübingen.

Patrick G. Grosz

Universität Tübingen

Deutsches Seminar

Wilhelmstr. 50

72074 Tübingen

Germany

patrick.grosz@uni-tuebingen.de 